\title{
Impact of Restructuring on Efficiency of Vietnam's Commercial Banks
}

\author{
TRAN HOANG NGAN \\ University of Economics HCMC - ngannh@ueh.edu.vn \\ TRAN PHUONG THAO \\ University of Economics HCMC - tranthao@ueh.edu.vn \\ NGUYEN HUU HUAN \\ University of Economics HCMC - huannguyen@ueh.edu.vn
}

\begin{abstract}
ARTICLE INFO
ABSTRACT

Article history:

The paper presents research on restructuring of Vietnam's system of

Received:

Aug. 272014

Received in revised form:

Dec. 172014 commercial banks by implementing a three-stage DEA/SFA approach to estimate of impact of the restructuring process on banking efficiency. The empirical findings show that rises and falls in banking efficiency are irregular because the restructuring process has not completed and that some banks gain higher efficiency scores while others, especially those affected by low performance of merged banks, witness sharp falls.
\end{abstract}

Accepted:

Mar. 262015

Keywords:

restructuring, efficiency, commercial banks, Data Envelopment Analysis, Stochastic Frontier Analysis. 


\section{Introduction}

The system of commercial banks plays an extremely important role in smoothing flows of capital, thereby promoting the socioeconomic development. After its 60 years of development, the Vietnam's system of commercial banks, comprising five stateowned banks, 33 joint stocks, four joint ventures, five foreign-owned banks, and 51 branches of foreign ones, has gradually improved its structure, size, and organization in spite of the current difficulties and limitations.

Severely impacted by the global economic recession, since 2008 Vietnam's commercial banks have faced various risks and challenges that could be seen in falling indicators of banking efficiency such as profitability, credit growth rate, and bad debt. Several measures, such as privatization, acquisitions and mergers, increased supply of liquidity to banks in need, and establishment of the Vietnam Asset Management Company (VAMC) that handles transactions and deals with bad debts burdened with by credit organizations, etc. have been taken by the SBV and commercial banks to restructure the system, overcome difficulties, and improve the banking efficiency.

To examine effects of the restructuring process on banking efficiency among Vietnam's commercial banks and based on previous studies, the paper investigates the impact of bank restructuring measures in recent years on their efficiency, and offer solutions to possible improvements of this process.

\section{Theoretical bases and literature review}

Different approaches have been adopted earlier to deal with the concept of bank restructuring. Particularly, Waxman (1998) suggests that the bank restructuring comprises many practices for not only resolving problems in some banks or a failed bank along with others still operating effectively, but also changing the structure of all components of the banking system, including the central bank, all commercial banks, banks for development and social policies, and the network of microcredit organizations. Meanwhile, Thoraneenitiyan and Avkiran (2009) indicate that the bank restructuring covers those measures in connection with bank ownership, such as acquisitions and mergers, foreign bank entry, and state interventions.

Bank restructuring programs produce certain effects on the operations of commercial banks and require participation of many involved parties. Goodhart (1988) maintains 
that the bank restructuring attracts three participants, the government, banks, and the public, all of whom would share both profits and losses during the bank restructuring process. Similarly, Berger, Demsetz, and Strahan (1999) show that the bank restructuring might improve banking performance when the balance between profits and risks for the involved parties is ensured.

\subsection{Systemic bank restructuring measures}

The systemic bank restructuring is implemented through the combination of various measures. Baliño et al. (1999) mention three forms of restructuring adopted by Asian banking system in the years 1997-1999, comprising mergers, closures, and state interventions. Dziobek and Pazarbasioglu (1998) survey the bank restructuring in 24 countries and figure out that these follow various methods, such as (i) new equity bought by government; (ii) closures of insolvent banks; (iii) mergers between local and foreign banks; (iv) mergers between local banks; (v) establishment of new asset management company; or (vi) privatization as a mode to change bank ownership structure. More recently Thoraneentiyan and Avkiran (2009) also refer to mergers, foreign bank participation, and state interventions as three widely employed instruments.

Generally, three popular bank restructuring instruments discussed in these studies consist of the following:

(1) Privatization of state-owned commercial banks

Privatization of state-owned commercial banks is one of the bank restructuring measures effectively adopted by various governments. Williams and Nguyen (2005) investigate the relationship between commercial bank performance and bank governance in South East Asia between 1990 and 2003 and find that state-owned banks perform less efficiently than private rivals; thus, privatization, in short and medium terms, might increase bank profit and total assets. Baer and Nazmi (2000) point out that state-owned banks regarded as underperformers aggravate the recession and badly affect the economic growth in Brazil, forcing Brazilian government and the central bank to conduct bank restructuring more actively by privatization of state-owned banks and intervene in the performance of insolvent ones.

(2) Merger

According to Hawkins and Turner (1999), bank restructuring may yield good results when a large bank acquires a smaller one that is in difficulty. The discovery is also that 
mergers could be hindered or delayed because it is, as often, consented to in a normal rather than a crisis period. Of all the bank restructuring measures, merger is the least costly.

Empirically, extensive evidence suggests that mergers of banks have certain connections with improvements in banking efficiency. Krishnasamy, Ridzwa, and Perumal (2004) provide evidence of improvements in banking performance in Malaysia before and after bank mergers in the years 2000-2001. They conclude that rises in productivity indexes are subject to technological advances in the whole banking system rather than in each individual bank. Peng and Wang (2004) also imply that bank mergers should lead up to the elevated bank efficiency in Taiwan.

(3) State intervention

Another measure taken by the government is temporarily controlling weak banks; the common practice is to recapitalize commercial banks. Governments may directly improve recovery of the banking system by repurchasing valuable papers or balancing long-term debts for weak banks (Barth, Nolle \& Rice, 1997). Borish, Long, and Noel (1995) argue that refinancing should be associated with changes in bank structure, such as ownership and executive board's management.

Government interventions in banking activities have been carried out in many countries in recent years. In Indonesia private shareholders, under the bank recapitalization scheme, are required to contribute $20 \%$ of the negative equity while the remaining $80 \%$ is provided by the government (Fane \& McLeod, 2002). Concerning Korean government, unsecured debts and subprime loans are repurchased in order to recapitalize private banks (Jeon \& Miller, 2005).

\subsection{Impacts of restructuring on performance of commercial banks}

These impacts have been discussed at length in previous studies by, for example, Peng and Wang (2004), Williams and Nguyen (2005), and Thoraneenitiyan and Avkiran (2009). These studies stress that various measures yield diverse results in banking performance. Similarly, the results of restructuring measures also differ over different economies.

Thoraneenitiyan and Avkira (2009) clarify relationships between bank mergers, foreign bank entry, state interventions, and bank efficiency in developed countries. Their 
findings indicate that mergers among local banks could improve efficiency of individual banks while restructuring measures, in general, fail to do so within the banking system.

Ordinarily, crises in developing countries are main causes of inefficiency in bank performance. Williams and Nguyen (2005), for example, investigate restructuring plans after the 1997 Asian financial crisis and realize that most banking authorities of these countries take several measures to improve performance of their banking systems and even encourage or force insolvent banks to accept mergers as a way to avoid dangers of bank failure and inefficiency. Their findings also detect positive effects of privatization among state banks.

Approvals for foreign bank entries have been adopted as a means of attracting foreign investors and technologies to reduce managerial cost and improve banking performance (Choi \& Clovutivat, 2004). Other studies, nevertheless, detect no evidence of improvement in banking performance after foreign bank entry (Berger \& DeYoung, 1997).

Various methods have also been used for estimating outcomes of systemic bank restructuring. Dziobek and Pazarbasioglu (1998) argue that "systemic bank restructuring aims to improve bank performance - that is, restore solvency and profitability, improve the banking system's capacity to provide financial intermediation between savers and borrowers, and restore public confidence," and they employ many indicators to measure the implementation of those three objectives, estimate different levels of the indicators, and compare the pre- and post-restructuring periods.

In their studies Kohers, Huang, and Kohers (2000), Kwan (2003), and Bonin, Hasan, and Wachtel (2005) use Data Envelopment Analysis (DEA) to examine efficiency per unit of operating expenses of the banking sector in different economies. Their test results indicate that bank efficiency has been improving over time after the restructuring.

Karim (2001) and Kohers et al. (2000) perform Stochastic Frontier Analysis (SFA) to estimate efficiency of bank restructuring. Examining different situations in four Southeast Asian countries before the 1997 Asian crisis, Karim (2001) points out that cost efficiency of Southeast Asian banks tends to fall in comparison with that in the precrisis years.

In sum, the systemic bank restructuring could be carried out in different models and methods of measuring efficiency of this process are relatively diverse. Of all the research methods, DEA and SFA are the most commonly applied. 


\section{Methodology and data}

\subsection{Methodology}

Adopting findings of previous studies, Avkiran and Rowlands (2008), and Thoraneenitiyan and Avkiran (2009) combine DEA and SFA models to evaluate banking efficiency. Based on their achievements, this research will apply the following threestage DEA/SFA model to also measure the efficiency:

- Stage 1: Employing DEA model to examine banking efficiency irrespective of the restructuring plan:

In this stage we assume that all surveyed banks always attempt to minimize input and maximize output. Thus, such variables as input and output are used to make returns to scale a non-oriented variation. The fractional program for estimating banking efficiency is presented in the following equation:

$$
\min \rho=\frac{1-\frac{1}{N} \sum_{i-1}^{N} s_{i}^{-} / x_{i}^{o}}{1+\frac{1}{N} \sum_{r-1}^{M} s_{i}^{+} / y_{i}^{o}}
$$

subject to

$$
\begin{aligned}
x^{o} & =X \lambda+s^{-} \\
y^{o} & =Y \lambda-s^{+} \\
\sum_{j-1}^{I} \lambda_{j} & =1 \\
\lambda \geq 0, s^{-} \geq 0, s^{+} & \geq 0
\end{aligned}
$$

where $\rho$ is a scalar that reports the efficiency score after performing DEA, $x \geq 0$ is a decision-making (DMU)s $\mathrm{N} x 1$ vector of inputs, $y \geq 0$ is a DMUs $\mathrm{M} \times 1$ vector of output, $\mathrm{X}=\left[\mathrm{x}_{1}, \ldots, \mathrm{x}_{\mathrm{I}}\right]$ is an $\mathrm{N} \mathrm{x} 1$ matrix input vectors in the sample, $\mathrm{Y}=\left[\mathrm{y}_{1}, \ldots, \mathrm{y}_{\mathrm{I}}\right]$ is an $\mathrm{M} \times$ I matrix of output vectors in the sample, $\mathrm{si}^{-}$and $\mathrm{si}^{+}$represent input and output slacks, respectively, and $\mathrm{X}^{\lambda}$ and $\mathrm{Y}^{\lambda}$ represent benchmark input consumption and output production. Inputs and outputs for the unit evaluated are indicated by the superscript "o" and the linear program is solved once for each unit in the sample. Imposing the constraint $\sum_{j-1}^{I} \lambda_{j}=1$ introduces variable returns to scale. A tested bank is deemed efficient if the optimal value for the objective function equals 1 . That is, for the tested banks to be efficient, all optimal input and output slacks must equal zero. The results from the stage 1 comprise efficiency scores of each DMU before the analysis of white noise, placed in the context of restructuring plan of each bank. 
- Stage 2: Applying SFA to input and output under due consideration of restructuring and statistical noise:

This stage aims at re-calculating input and output slacks (inefficiencies) attributable to environmental effects (restructuring measures), statistical noise (managerial inefficiency). Input and output slacks from the stage 1 are regressed through SFA on environmental variables to have adjusted input slacks and output slacks in a restructuring context.

According to Avkiran and Rowlands (2008), the general function of the SFA regressions for input slacks and output slacks is represented in Equations (2), (3), (4), and (5).

$$
\begin{aligned}
& s_{i j}^{-}=f^{i}\left(z_{j} ; \beta^{i}\right)+v_{i j}+u_{i j} \quad, i=1, \ldots, N \text { và } j=1, \ldots, I \\
& s_{i j}^{+}=f^{i}\left(z_{j} ; \beta^{r}\right)+v_{r j}+u_{r j} \quad, r=1, \ldots, M \text { và } j=1, \ldots, I \\
& f^{i}\left(z_{j} ; \beta^{i}\right)=\alpha+z_{j} \beta^{*}(*=\mathrm{i}, \mathrm{r}) \\
& v_{i j}, v_{r j} \sim \mathrm{N}\left(0, \sigma_{v}^{2}\right) ; u_{i j}, u_{r j} \sim \mathrm{F}
\end{aligned}
$$

where $s_{i j}^{-}$and $s_{i j}^{+}$are the stage 1 slacks in the $\mathrm{i}^{\text {th }}$ input and the $\mathrm{r}^{\text {th }}$ output for the $\mathrm{j}^{\text {th }}$ unit, $f^{i}\left(z_{j} ; \beta^{i}\right)$ represents logarithm of variable Input Slacks or Output Slacks, $z_{j}$ is the vector representing environmental variables, $\beta^{i}$ and $\beta^{r}$ are parameter vectors for estimator, and $v_{i j}+u_{i j}$ and $v_{r j}+u_{r j}$ are composed error structure where $v_{i j}, v_{r j} \mathrm{~N}(0$, $\sigma^{2}$ ) represents white noise and ${ }^{u_{i j}}, u_{r j} \geq 0$ represents managerial inefficiency.

Suppose that estimate of managerial inefficiency is based on common distribution of half-normal distribution (Coelli, Rao, O'Donnell, and Battese, 2005) with error changing systematically over time - performing SFA usually follows two steps: (1) estimating parameter $(\theta)$ of the model with function (ML) $\mathrm{Y}(\theta)$, where $\theta=\left(\alpha, \beta^{s}, \sigma_{w}^{z}, \sigma_{v}^{z}\right)$, , and (2) estimating the inefficiency through mean of distribution $\mathrm{f}\left(\mathrm{u}_{\mathrm{i}} \mid \hat{\varepsilon}_{\mathrm{i}}=\mathrm{u}_{\mathrm{i}}+\mathrm{v}_{\mathrm{i}}\right)$ where $\hat{\varepsilon}_{\mathrm{i}}=$ $f^{i}\left(z_{j} ; \beta^{i}\right)-\widehat{\alpha}-z_{j} \widehat{\beta^{*}}$. This function comes from the assumption about the independent variable between $u_{i}$ and $v_{i}$.

$$
\begin{aligned}
& \int_{0}^{+\infty} f_{u}\left(u_{i}\right) f_{v}\left(\varepsilon_{i}-u_{i}\right) \mathrm{d} u_{i} \\
& \nmid(\theta)=\sum_{i=1}^{n} \log f_{\varepsilon}(\varepsilon \mid \theta)
\end{aligned}
$$


As with the parameters acquired from SFA regression function, we examine input and output variables after their being adjusted by environmental effects and white noise analysis. It can be observed that input values in banks that benefit from favorable environment were adjusted upwards, thus lowering their efficiency scores, while upward adjustment was made to output values of banks that suffered bad effects from uncertain environment.

- Stage 3: Analyzing efficiency of each bank under environmental effects and statistical noise:

Stage 3 is a repeat of slacks-based measure (SBM) of efficiency (DEA) analysis in Stage 1, using variables Input Slacks and Output Slacks adjusted in Stage 2 (SFA). Results from Stage 3 represent DEA analysis of bank efficiency under environmental effects after statistical noise is handled.

\subsection{Research data}

To examine the restructuring efficiency among Vietnam's commercial banks, the authors employed data of 15 banks (four state-owned and ten joint stock banks) in the years 2007-2013, gathered from Bankscope database and relevant financial statements. Variables applied in the DEA/SFA model are as follows:

- Input and output variables in the model of efficiency:

The DEA model comprises three input variables and three output variables. Based on the assumption that the principal role of a bank is to smooth flows of capital between depositors and borrowers at the possibly lowest cost, DEP (deposit), LCAP (labor capital), and PCAL (physical capital) are input variables for the process of bank's generating added value. Particularly, DEP represents total deposits adopted as input capital for commercial banks; LCAP represents labor cost that covers the expense on commercial banking employment while PCAP is measured by other operating expenses as shown in the entry "other expenses" in the balance sheet.

Three output variables that reflect traditional and non-traditional lending service are LOAN (loan), INV (income from investment and other assets), and FEE (income from bank fees). Total loan is adjusted for convenience in the comparison of loan quality among banks while investments and other assets measure the efficiency of bank's portfolio management.

- Environmental variables: 
Environmental effects (zj) could bias value of initial efficiency analysis. Bank restructuring measures and a variable controlling bank size are included in Stage 2. Due to constraints of data gathering, three dummy variables are used for checking impacts of restructuring on bank efficiency. These, comprising MER (merger), SI (state intervention) and COP (privatization), take the value of 1 if restructuring measures are taken at time $t$ and otherwise, zero.

Based on previous studies, the paper suggests the following expected signs for these variables:

\section{Table 1}

Expected signs of restructuring dummy variables

\begin{tabular}{lll}
\hline Restructuring measure & Symbol & Expected sign \\
\hline Merger & MER & - \\
State intervention & SI & + \\
Privatization & COP & + \\
\hline
\end{tabular}

\section{Results and discussion}

\subsection{Data descriptions}

Table 2 presents statistical descriptions of primary data of input and output variables.

\section{Table 2}

Statistical descriptions of primary data of input and output variables

\begin{tabular}{llllll}
\hline Variable (VND1,000 billion) & Obs. & Mean & Std. Dev. & Min & Max \\
\hline DEP & 100 & 140962 & 130998 & 9896.7 & 542186 \\
LCAP & 99 & 1485.9 & 1849.5 & 28.29 & 9787.2 \\
PCAP & 99 & 1402 & 1471.3 & 45.29 & 7450.3 \\
LOAN & 100 & 98147 & 111830 & 4175.4 & 470950 \\
INV & 100 & 25140 & 20423 & 774.31 & 86935 \\
FEE & 99 & 4749.6 & 5346.4 & 89.46 & 26609 \\
SIZE & 100 & 169871 & 153448 & 12367 & 617859 \\
\hline
\end{tabular}


In the process of data gathering values of LCAP, PCAP and FEE from a commercial bank were not sufficiently reported because the bank did not keep full records in its first years of operation, and as a result, the dataset lacked one observation. Generally, input variables collected from the primary data exhibited great volatilities. For example, standard deviation was pretty high, equaling at least $90 \%$ of the mean of input variables while the dispersion (difference between max and min) was very large. This implies that fluctuation is rather wide in spite of the analysis of bank performance in such a short period as seven years. The model, therefore, might be heteroskedastic.

\section{Table 3}

Descriptions of primary data of restructuring dummy variables

\begin{tabular}{lccccccc}
\hline & 2007 & 2008 & 2009 & 2010 & 2011 & 2012 & 2013 \\
\hline MER & 0 & 0 & 0 & 0 & 0 & 1 & 2 \\
SI & 0 & 0 & 4 & 4 & 4 & 4 & 4 \\
COP & 0 & 1 & 2 & 2 & 3 & 3 & 3 \\
\hline
\end{tabular}

The above table shows changes in the number of restructured banks in the dataset for the years 2007-2013.

\subsection{Results of calculations}

- Measurement of efficiency of commercial banks based on initial DEA:

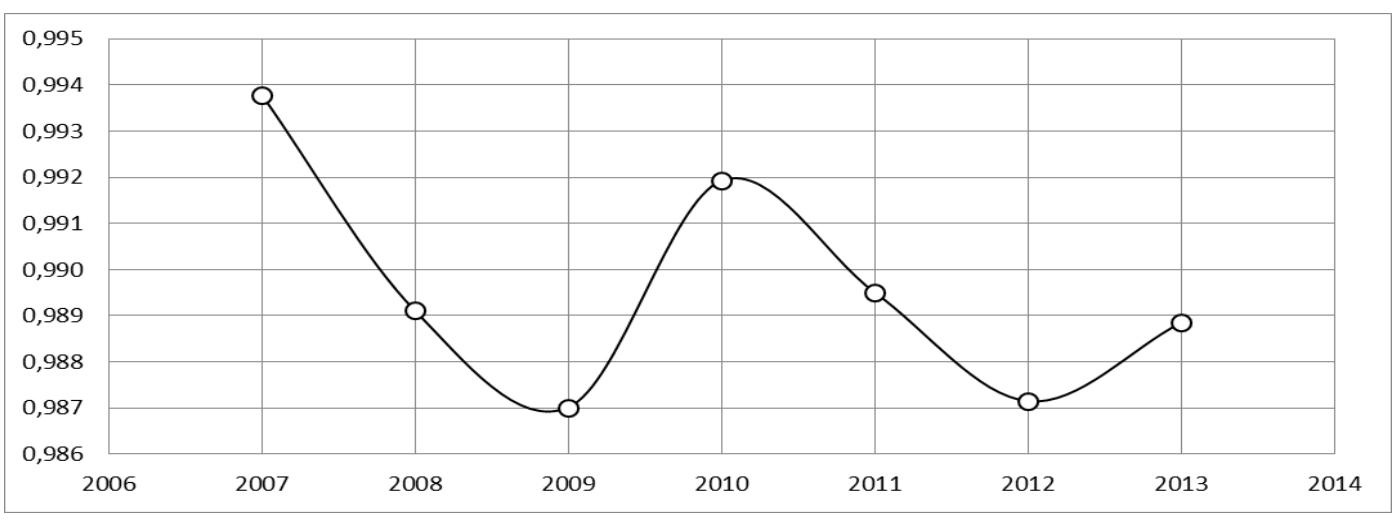

Fig. 1. Efficiency score in Stage 1 
The results of DEA in Stage 1 allow an estimate of an efficiency frontier including all observations over seven years of 15 local commercial banks. Stage 1's results show that efficiency scores of all banks are very high and almost free from fluctuation. The average efficiency score in 2011 was $99 \%$, falling by 0.43 percentage point from the 2007 average and 0.11 percentage point from the 2010 average. Although the global economy faced great difficulties in 2009, they had no visible effect on Vietnam's banks and financial system, and the efficiency scores in this period stayed high $(98.7 \%)$ or fell slightly. This result might be due to the fact that Vietnam's banks had just started to integrate into the world market and enjoyed a high economic growth rate. In the years 2009-2011, however, the Vietnamese economy experienced wide fluctuations, which made the efficiency score fall slightly (99\% in 2011).

This change did not properly reflect real problems for the banking system in general and individual banks in particular. According to the SBV, many banks faced great difficulties, especially in 2011 when bad debt in the whole system rose to 8.6\%; loan quality fell sharply; shortage of liquidity became serious with the result that inter-bank rate mounted to $30 \%$ per year at times and deposit rates offered by many banks surpassed the SBV-set ceiling, which led to many bank closures and mergers, as in several cases of Viet Nam Tin Nghia, De Nhat, and Habubank. The bank efficiency score in this period, therefore, fell considerably.

Defects of the model come from the fact that environmental effects, or variables representing bank restructuring measures, and analysis of white noise have not been introduced to the model. Previous studies show that the low efficiency scores could be affected by the white noise and failure to consider impacts of environment factors on the bank efficiency. These assumptions, therefore, will be checked in Stage 2 by the SFA regression. There might also be some mistakes in gathering data, but this possibility is rejected because the data are from Bankscope.

- Results of SFA regression and statistical noises with bank restructuring taken into consideration:

The results presented in Table 4 show that in the 2012-2013 period impact of MER on bank efficiency is statistically significant but not profound enough. Only six out of 12 regression coefficients are statistically significant while dummy variables SI and COP have statistically significant effects on input and output independent variables. The Gamma values in Table 4 are all greater than zero in the years 2008, 2009, 2011, and 
2012 and statistical significant, which implies that fluctuations in values of variables Input and Output Slacks predicted for those years are due to managerial inefficiency and vice versa.

Coefficients of the restructuring variables are noteworthy. Effects of MER on independent variables (Input Slacks and Output Slacks) are only statistical significant in 2012 and 2013 and not remarkable enough. The reason may be that merger, as a restructuring measure, has just been taken in those two years and only a few of commercial banks made disclosure after mergers, which prevents the identification of efficiency and impacts of mergers on banks and the economic health in general (cases of mergers involving SCB, Viet Nam Tin Nghia, and De Nhat Banks initiated in 2012, but before such no merger was reported). Meanwhile, coefficient of the variable SI demonstrates positive and statistically significant effects on Input Slacks and Output Slacks in most of the surveyed years.

As predicted earlier, banks with effects of state interventions (recapitalization, rediscounting, or provision of new working capital for state-owned companies) employ more optimal inputs and outputs than those without. Specifically, when SI increases by one percentage point in the years 2009-2011, the increase in the mean of Input Slacks is smaller than the average increase of Output Slacks, which implies that in this period, state-owned commercial banks were not efficient as expected in spite of state interventions. Contrarily, when SI increased by 1 percentage point in 2013, increases in the mean of Input Slacks is greater than the average increase of Output Slacks, which means that state-owned banks show encouraging signs after restructuring. This is quite true for the case of Vietnam's banks.

Additionally, Table 4 shows that the regression coefficient of COP yields statistically significant effects $(10 \%)$ on Input Slacks and Output Slacks, which implies that the privatized banks perform more efficiently than those without privatization. 


\section{Table 4}

Summary of later SFA results

\begin{tabular}{|c|c|c|c|c|c|c|c|c|c|c|c|c|}
\hline & \multicolumn{6}{|c|}{2008} & \multicolumn{6}{|c|}{2009} \\
\hline \multirow[t]{3}{*}{ Ind. variable } & \multicolumn{5}{|c|}{ Dependent variable } & \multicolumn{7}{|c|}{ Dependent variable } \\
\hline & \multicolumn{3}{|c|}{ Input slacks } & \multicolumn{2}{|c|}{ Output slacks } & \multicolumn{4}{|c|}{ Input slacks } & \multicolumn{3}{|c|}{ Output slacks } \\
\hline & $\begin{array}{l}\stackrel{0}{0} \\
\stackrel{1}{\Delta}\end{array}$ & 宅 & 这 & Z & 立 & 画 & $\begin{array}{l}\stackrel{0}{\underline{1}} \\
\stackrel{1}{0}\end{array}$ & 己્త & 这 & Z & 文 & 岀 \\
\hline Constant & 10.52 & - & 6.67 & 10.46 & 9.48 & 6.92 & 10.92 & 6.79 & - & 10.55 & 10.43 & 7.32 \\
\hline MER (-) & 0 & - & 0 & 0 & 0 & 0 & 0 & 0 & - & 0 & 0 & 0 \\
\hline $\mathrm{SI}(+)$ & 0 & - & 0 & 0 & 0 & 0 & 0.40 & 0.76 & - & 0 & 0.17 & 0.78 \\
\hline $\mathrm{COP}(+)$ & 1.54 & - & 0.93 & 1.25 & 1.26 & 1.72 & 1.15 & 0.82 & - & 1.37 & 0.06 & 1.14 \\
\hline slacksize & -5.08 & - & -2.50 & -2.82 & -2.95 & -7.32 & -5.38 & -2.55 & - & -4.09 & -3.24 & -3.51 \\
\hline gamma & $\neq 0$ & - & $\neq 0$ & $\neq 0$ & $\neq 0$ & 0 & $\neq 0$ & $\neq 0$ & - & $\neq 0$ & $\neq 0$ & 0 \\
\hline Loglikelihood function & -8.67 & - & -11.4 & -8.59 & -14.63 & -10.6 & -5.76 & -10.28 & - & -9.86 & -4.80 & -8.26 \\
\hline Mean slacks & 10.84 & 6.08 & 6.21 & 10.36 & 9.13 & 7.37 & 11.22 & 6.36 & 6.43 & 10.76 & 9.36 & 7.65 \\
\hline & \multicolumn{6}{|c|}{2010} & \multicolumn{6}{|c|}{2011} \\
\hline \multirow[t]{3}{*}{ Ind. variable } & \multicolumn{6}{|c|}{ Dependent variable } & \multicolumn{6}{|c|}{ Dependent variable } \\
\hline & \multicolumn{3}{|c|}{ Input slacks } & \multicolumn{2}{|c|}{ Output slacks } & & \multicolumn{2}{|c|}{ Input slacks } & & \multicolumn{2}{|c|}{ Output slacks } & \\
\hline & $\begin{array}{l}0 \\
\stackrel{\Upsilon}{1} \\
\frac{1}{0}\end{array}$ & 穵 & 导 & Z & 之 & 点 & $\begin{array}{l}0 \\
\stackrel{0}{10} \\
\text { 10. }\end{array}$ & 密 & 宅 & Zֵ & 㐫 & 䅣 \\
\hline Constant & 11.75 & 6.38 & 6.54 & 10.70 & 10.18 & 8.40 & 11.95 & 7.64 & 7.41 & 11.32 & 10.52 & 8.85 \\
\hline MER (-) & 0 & 0 & 0 & 0 & 0 & 0 & 0 & 0 & 0 & 0 & -0.89 & 0 \\
\hline $\mathrm{SI}(+)$ & 0 & 0 & 0.65 & 0 & 0.35 & 0 & 0 & 0.59 & 0 & 0 & 0.41 & 0.53 \\
\hline $\mathrm{COP}(+)$ & 0.82 & 1.66 & 1.02 & 1.46 & 0.45 & 0.69 & 0.76 & 0.43 & 0.61 & 1.01 & 0.24 & 0.50 \\
\hline slacksize & -5.38 & -6.41 & -4.59 & -6.91 & -318.90 & -4.04 & -5.519 & -3.3006 & -3.19 & -4.71 & -1.76 & -4.2394 \\
\hline gamma & $\neq 0$ & 0 & 0 & 0 & 0 & & $\neq 0$ & $\neq 0$ & $\neq 0$ & $\neq 0$ & $\neq 0$ & $\neq 0$ \\
\hline Log likelihood function & -5.18 & -10.5 & -8.55 & -9.32 & -8.10 & -7.51 & -5.03 & -5.87 & -7.59 & -8.07 & -2.40 & -6.65 \\
\hline Mean slacks & 11.59 & 6.66 & 6.75 & 11.09 & 9.97 & 7.96 & 11.87 & 7.19 & 7.16 & 11.25 & 10.13 & 8.46 \\
\hline
\end{tabular}




\begin{tabular}{|c|c|c|c|c|c|c|c|c|c|c|c|c|}
\hline \multirow[t]{3}{*}{ Ind. variable } & \multicolumn{6}{|c|}{ Dependent variable } & \multicolumn{6}{|c|}{ Dependent variable } \\
\hline & \multicolumn{3}{|c|}{ Input slacks } & \multicolumn{2}{|c|}{ Output slacks } & \multicolumn{4}{|c|}{ Input slacks } & \multicolumn{3}{|c|}{ Output slacks } \\
\hline & $\begin{array}{l}0 \\
\stackrel{1}{1} \\
\text { 苟 }\end{array}$ & 宅 & 灾 & $\underset{্}{Z}$ & Z & 岀 & $\begin{array}{l}0 \\
\stackrel{1}{10} \\
0\end{array}$ & 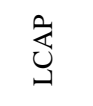 & 这 & $\underset{্}{Z}$ & 之 & 窐 \\
\hline Constant & 10.89 & 7.65 & 7.70 & 11.07 & 9.33 & 7.56 & 11.92 & 6.84 & 7.59 & 11.57 & 10.56 & 8.07 \\
\hline MER (-) & 0.66 & -1.05 & -0.28 & 0 & 0 & 0 & -0.12 & 0 & -0.20 & 0.03 & 0 & 0 \\
\hline SI $(+)$ & 1.02 & 0 & 0.33 & 0 & 1.05 & 0 & -0.09 & 0.70 & 0.01 & 0.03 & 0 & 0 \\
\hline $\mathrm{COP}(+)$ & 0.95 & 0.64 & 0.24 & 1.46 & 0.57 & 1.75 & 1.17 & 1.19 & 0.91 & 1.26 & 0.81 & 1.51 \\
\hline slacksize & 1.43 & -2.66 & -2.93 & 24.02 & 0.76 & 1.27 & 0 & -17.54 & 0 & -1.75 & 0 & -24.58 \\
\hline gamma & $\neq 0$ & $\neq 0$ & $\neq 0$ & $\neq 0$ & 0 & $\neq 0$ & 0 & 0 & 0 & 0 & 0 & 0 \\
\hline Log likelihood function & -1.87 & -4.28 & 0.74 & -7.73 & -7.89 & -11.1 & 1.85 & -2.85 & 0.83 & -0.93 & 1.05 & -4.51 \\
\hline Mean slacks & 11.89 & 7.25 & 7.46 & 11.34 & 10.15 & 8.52 & 11.95 & 7.27 & 7.48 & 11.48 & 10.34 & 8.42 \\
\hline
\end{tabular}

- Results of DEA of efficiency after data adjustment according to bank restructuring and statistical noises:

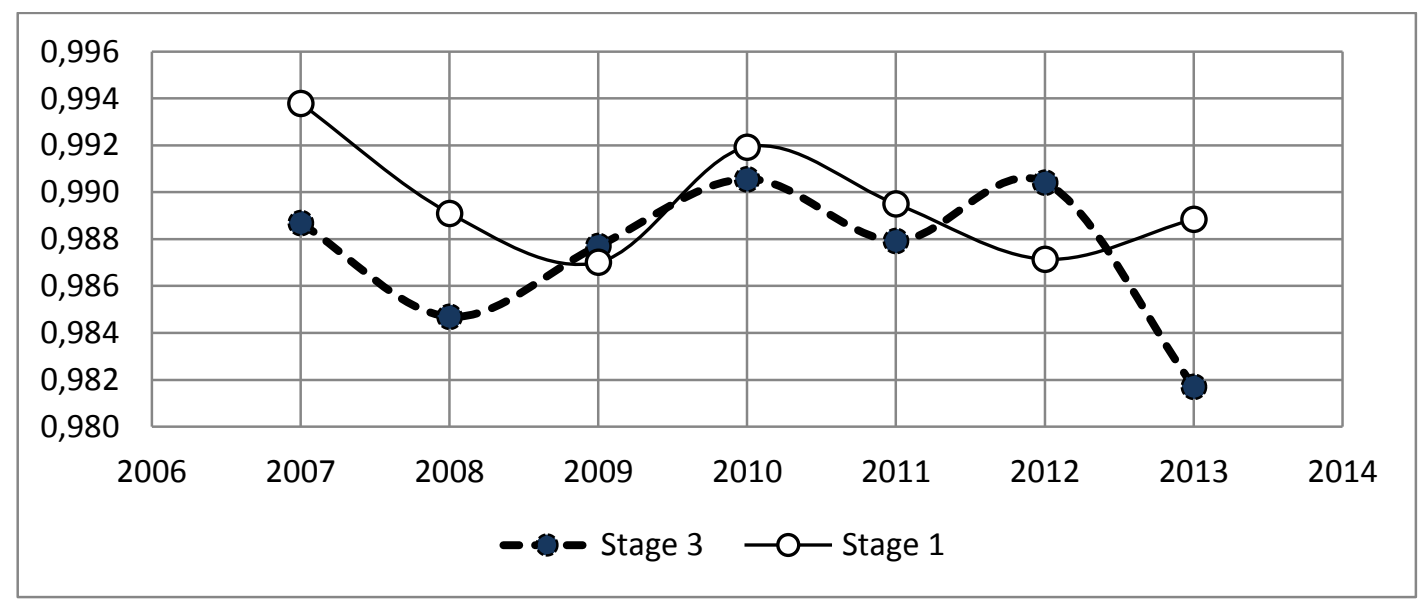

Fig. 2. Efficiency score of the banking system of Stage 3

The efficiency scores in Stage 3 before and after adjustments to changes in operating environment and effects of statistical noise differed considerably. Figure 2 comparing the average efficiency scores of Stage 2 and Stage 3 illustrates that the scores after adjustments are more realistic. The global economic crisis profoundly affected operations of the banking system and Vietnam's economy as well. Direct supports from 
the state to commercial banks and privatization have enabled the improvement of banking efficiency. The result shows that restructuring measures and analysis of statistic noise have effects on the estimate of bank efficiency. The evidence reveals that the efficiency scores changed considerably after Stage 2, and variables included in the analysis of statistical noise are environmental ones, most of which have impacts on performance of commercial banks.
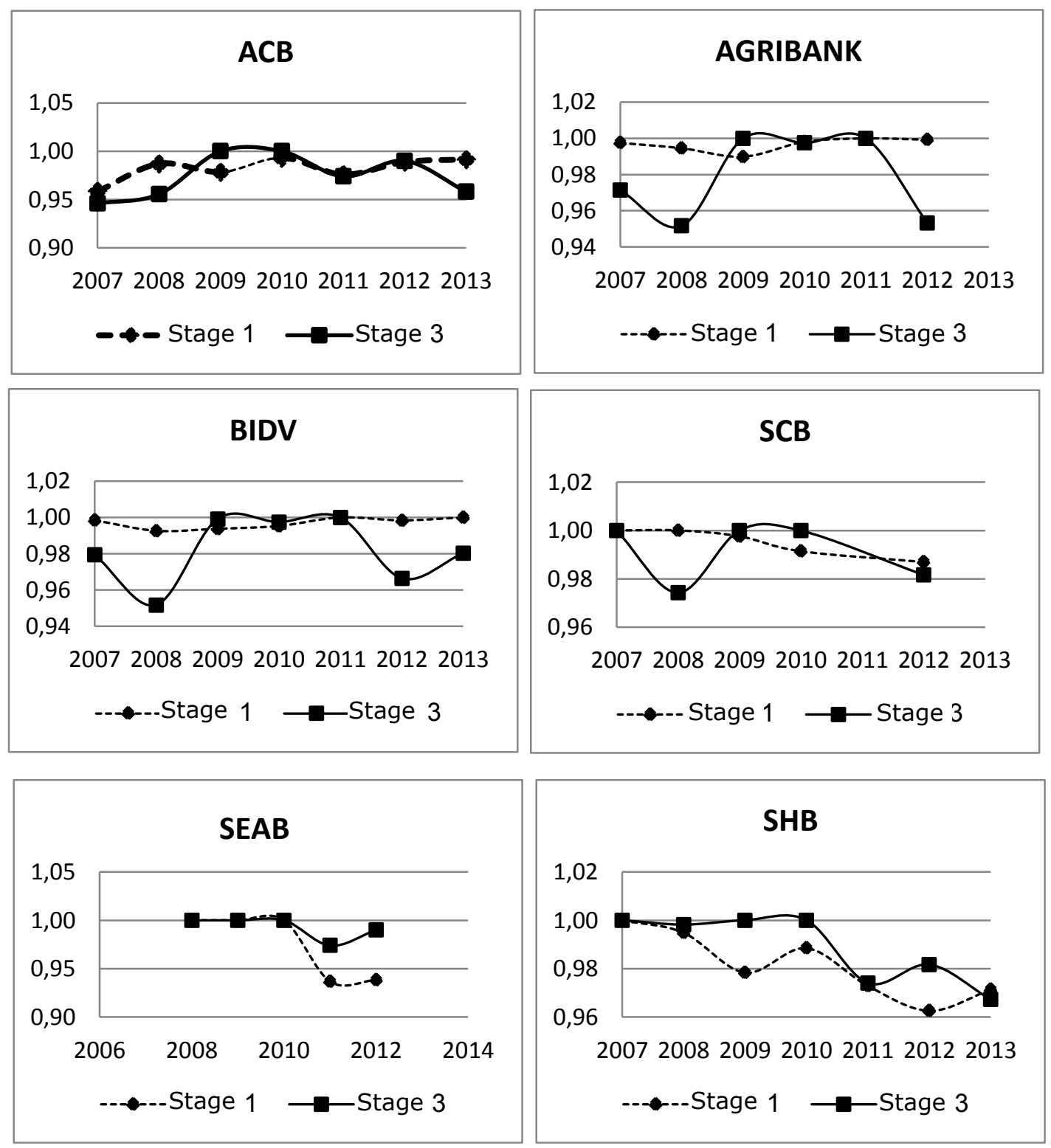

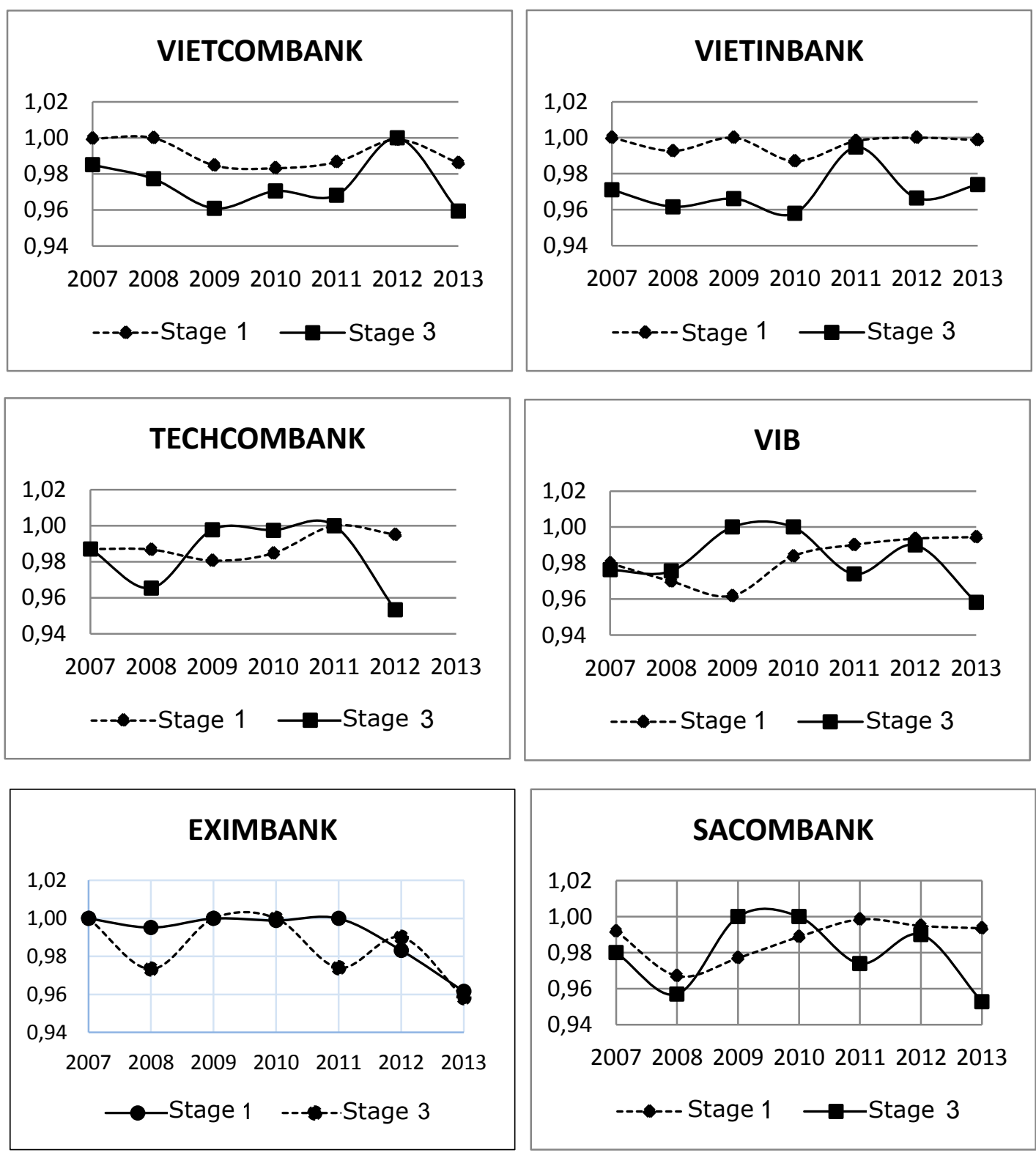

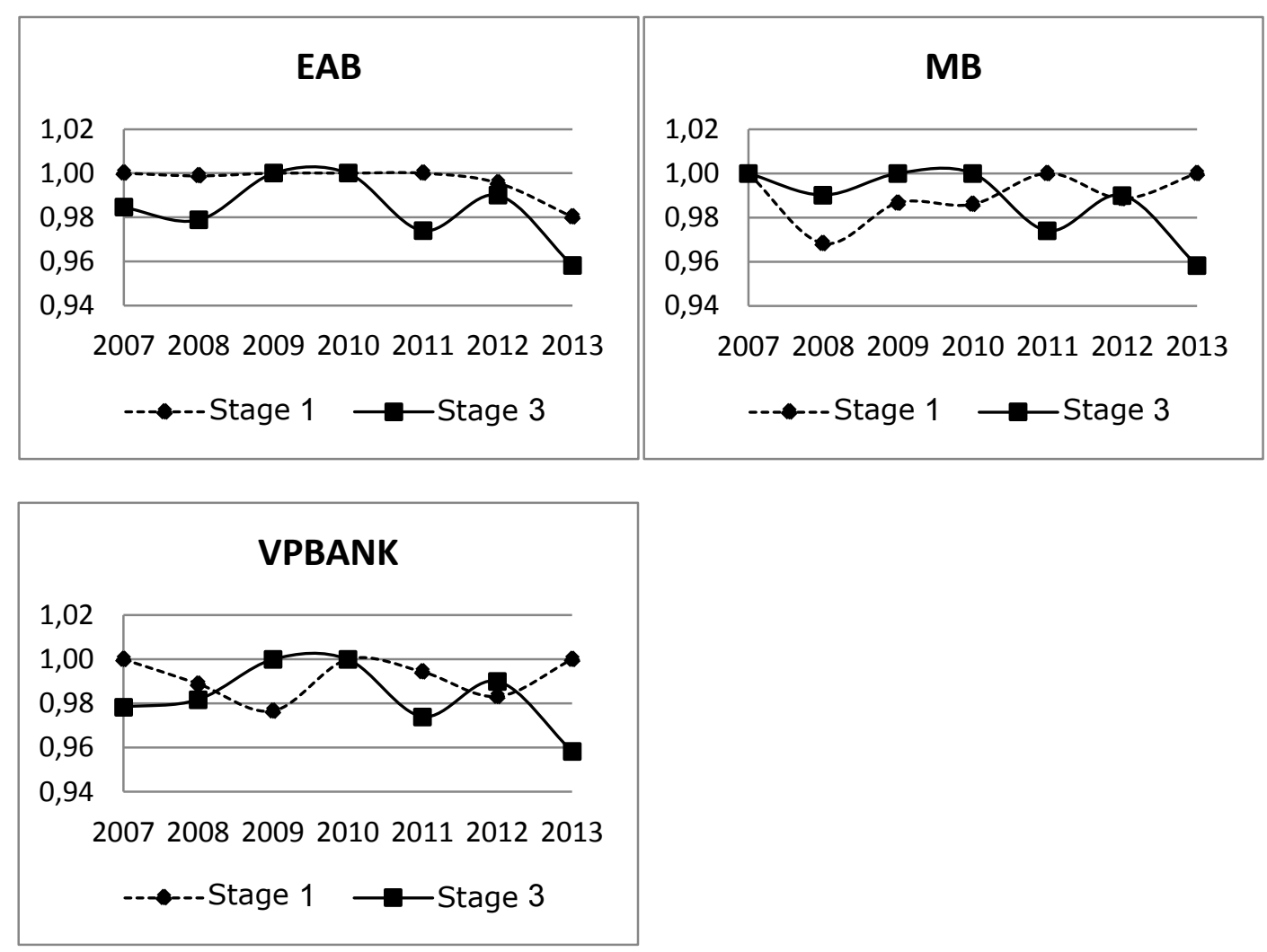

Fig. 3. Efficiency scores of surveyed banks in Stage 3

Three formerly state-owned banks - BIDV, Vietinbank and Vietcombank - have their efficiency scores remarkably improved after privatization while the 2012 Agribank score was of the lowest level in spite of the state support, which demonstrates that privatization is important to bank performance.

Additionally, the results also indicate that efficiency scores of banks engaging in mergers fell sharply because these were either merged with weak bank or affected by other factors. This finding is compliant with expected signs established in the beginning. For example, SCB score fell by 2-3 percentage points and SHB score by approximately two percentage points in comparison with those of the pre-merger period, 2011. 


\section{Conclusions, policy recommendations, and directions for further studies}

\subsection{Conclusions}

In an effort to examine impacts of restructuring process on performance of commercial banks, the research applies the three-stage DEA/SFA to estimate effects of three of the restructuring measures - mergers, state interventions and privatization - on bank operations.

The results show that mergers affected the efficiency of commercial banks in 20122013, and efficiency scores of merged banks fell sharply after they were merged with small and weak banks.

Banks affected by state interventions used inputs and outputs better than those without state interventions. The results show that when SI increases by one percentage point, the increase in the mean of Input Slacks and Output Slacks is smaller than one percentage point, which implies that state-owned commercial banks were less efficient than were expected in spite of state interventions. This is quite true in the case of Vietnam's banks.

Additionally, the regression coefficient of COP produces statistically significant effects $(10 \%)$ on Input Slacks and Output Slacks, which implies that privatized banks were more efficient than those which have yet to be privatized.

\subsection{Policy recommendations}

The findings of the research allow the authors to suggest some solutions to improve the performance of commercial banks in particular and the whole banking system in general by means of restructuring measures.

Commercial banks play an important role in the economy although they face a high degree of risk. When a crisis breaks out in the banking system, governments usually rescue weak banks to prevent multiple chains of collapses. This effort is very costly, becoming a burden to taxpayers and furthermore causes moral hazard or habit of relying on external support among commercial banks. To keep these bad practices from arising, measures must be taken and intended to reinforce banking safety, enhance supervision of banking authorities, and also adjust banking regulations in accordance with changes in the market. Privatization could be applied to Agribank, the last state-owned 
commercial bank, to nurture such an efficient performance of this biggest commercial banks in Vietnam.

More support could be given to banks in which weak banks are incorporated toward banking downsizing and their enhanced performance.

Financial support from the state should be fairly distributed based on objective criteria along priority shifted from state-owned banks in order to limit moral hazard and improve efficiency of the whole banking system.

To help Vietnam's commercial banks keep pace with their Southeast Asian counterparts, the banking authority could require banks to adopt Basel II criteria and increase their chartered capital to ensure solvency and other standard operations.

Successful banking restructuring process should roughly coincide with accelerated economic restructuring, especially to state-owned corporations and groups.

\subsection{Directions for future studies}

Besides the aforementioned findings on restructuring effects on banking efficiency, the research has its own limitations as follows:

- The research model only obtains a relative accuracy because of its limited samples (surveying only 15 banks in a seven-year period). Data for the variables Input and Output are not sufficient because it is difficult to collect data from small-sized banks.

- Collecting adequate data of all restructured banks seems to be another obstacle. The restructuring plans have recently been carried out by various banks, most of which have no full report on their operations, which led to difficulties in gathering data from those implementing the restructuring.

- Restructuring is still a new concept to most commercial banks while Vietnam's banking system is just in its first stage of development, and as a result, only a few of the banks engage in this process, which to some extent affects the consistency of the achieved research findings.

Regarding future studies on the bank restructuring, it is essential to expand its scope and data. Additionally, introducing additional variables that reflect diverse forms of restructuring or quantifying these is expected to provide a more vivid overall panorama on the restructuring of Vietnam's commercial banks 


\section{References}

Avkiran, N. K., \& Rowlands, T. (2008). How to better identify the true managerial performance: State of the art using DEA. Omega, 36(2), 317-324.

Baer, W., \& Nazmi, N. (2000). Privatization and restructuring of banks in Brazil. The Quarterly Review of Economics and Finance, 40(1), 3-24.

Baliño, T. J. T., Lingren, C-J., Enoch, C., Quyntyn, M., Gulde, A-M., \& Teo, L. (1999). Financial sector crisis and restructuring: Lessons from Asia. Retrieved from http://www.imf.org/external/pubs/ft/op/opfinsec/

Barth, J. R., Nolle, D. E., \& Rice, T. N. (1997). Commercial banking structure, regulation, and performance: An international comparison. Managerial Finance, 23(11), 1-39.

Berger, A. N., Demsetz, R. S., \& Strahan, P. E. (1999). The consolidation of the financial services industry: Causes, consequences, and implications for the future. Journal of Banking \& Finance, 23(2-4), 135-194.

Berger, A. N., \& DeYoung, R. (1997). Problem loans and cost efficiency in commercial banks. Journal of Banking \& Finance, 21(6), 849-870.

Bonin, J. P., Hasan, I., \& Wachtel, P. (2005). Privatization matters: Bank efficiency in transition countries. Journal of Banking \& Finance, 29(8-9), 2155-2178.

Borish, M. S., Long, M. F., \& Noel, M. (1995). Restructuring banks and enterprises: Recent lessons from transition countries (World Bank Discussion Papers No. WDP 279). Washington, D.C.: The World Bank. Retrieved from http://documents.worldbank.org/curated/en/ 1995/01/697722/restructuring-banks-enterprises-recent-lessons-transition-countries

Choi, D. F. S., \& Clovutivat, W. (2004). The relaxation of foreign ownership limits and market integration: The case of Thailand. Managerial Finance, 30(7), 78-89.

Coelli, T. J., Rao, D. S. P., O'Donnell, C. J., \& Battese, G. E. (2005). Data Envelopment Analysis. In An introduction to efficiency and productivity analysis (pp. 161-181). New York, NY: Springer Science \& Business Media.

Dziobek, C., \& Pazarbasioglu, C. (1998). Lessons from systemic bank restructuring (IMF Working Paper 97/161). Washington, D.C.: International Monetary Fund.

Fane, G., \& McLeod, R. H. (2002). Banking collapse and restructuring in Indonesia, 1997-2001. Cato Journal, 22(2), 277-295

Goodhart, C. A. E. (1988). The evolution of central banks. Cambridge, MA: The MIT Press.

Hawkins, J., \& Turner, P. (1999). Bank restructuring in practice: An overview. In Bank restructuring in practice, BIS Policy paper 6. Basel, Switzerland: Bank for International Settlement. 
Jeon, Y., \& Miller, S. M. (2005). Performance of domestic and foreign banks: The case of Korea and the Asian financial crisis. Global Economic Review, 34(2), 145-165.

Kohers, T., Huang, M-H., \& Kohers, N. (2000). Market perception of efficiency in bank holding company mergers: The roles of the DEA and SFA models in capturing merger potential. Review of Financial Economics, 9(2), 101-120.

Krishnasamy, G., Ridzwa, A. H., \& Perumal, V. (2004). Malaysian post merger banks' productivity: Application of Malmquist Productivity Index. Managerial Finance, 30(4), 63-74.

Kwan, S. H. (2003). Operating performance of banks among Asian economies: An international and time series comparison. Journal of Banking \& Finance, 27(3), 471-489.

Peng, Y-H., \& Wang, K. (2004). Cost efficiency and the effect of mergers on the Taiwanese banking industry. The Service Industries Journal, 24(4), 21-39.

Thoraneenitiyan, N., \& Avkiran, N. K. (2009). Measuring the impact of restructuring and countryspecific factors on the efficiency of post-crisis East Asian banking systems: Integrating DEA with SFA. Socio-Economic Planning Sciences, 43(4), 240-252.

Waxman, M. (1998). A legal framework for systemic bank restructuring. Washington, D. C.: The World Bank. Retrieved from http://documents.worldbank.org/curated/en/1998/06/5794293/legalframework-systemic-bank-restructuring

Williams, J., \& Nguyen, N. (2005). Financial liberalisation, crisis, and restructuring: A comparative study of bank performance and bank governance in South East Asia. Journal of Banking \& Finance, 29(8-9), 2119-2154. 